\title{
Mitigating the impacts of air pollutants in Nepal and climate co-benefits: a scenario-based approach
}

\author{
Amrit M. Nakarmi ${ }^{1,2}$ (D) Bikash Sharma ${ }^{3} \cdot$ Utsav S. Rajbhandari ${ }^{1} \cdot$ Anita Prajapati ${ }^{1} \cdot$ Christopher S. Malley $^{4} \cdot$ \\ Johan C. I. Kuylenstierna ${ }^{4} \cdot$ Harry W. Vallack ${ }^{4}$. Daven K. Henze ${ }^{5}$. Arnico Panday ${ }^{3}$
}

Received: 8 May 2018 / Accepted: 17 January 2020 / Published online: 27 January 2020

(C) The Author(s) 2020

\begin{abstract}
Short-lived climate pollutants (SLCPs) including black carbon (BC), methane $\left(\mathrm{CH}_{4}\right)$, and tropospheric ozone $\left(\mathrm{O}_{3}\right)$ are major climate forcers after carbon dioxide $\left(\mathrm{CO}_{2}\right)$. These SLCPs also have detrimental impacts on human health and agriculture. Studies show that the Hindu Kush Himalayan (HKH) region, which includes Nepal, has been experiencing the impacts of these pollutants in addition to greenhouse gases. In this study, we derive a national-level emission inventory for SLCPs, $\mathrm{CO}_{2}$, and air pollutants for Nepal and project their impacts under reference (REF) and mitigation policy (POL) scenarios. The impacts on human health, agriculture, and climate were then estimated by applying the following: (1) adjoint coefficients from the Goddard Earth Observing System (GEOS)-chemical transport model that quantify the sensitivity of fine particulate matter $\left(\mathrm{PM}_{2.5}\right)$ and surface $\mathrm{O}_{3}$ concentrations in Nepal, and radiative forcing in four latitudinal bands, to emissions in $2 \times 2.5^{\circ}$ grids, and (2) concentration-response functions to estimate health and crop loss impacts in Nepal. With the mitigating measures undertaken, emission reductions of about $78 \%$ each of $\mathrm{BC}$ and $\mathrm{CH}_{4}$ and $87 \%$ of $\mathrm{PM}_{2.5}$ could be achieved in 2050 compared with the REF scenario. This would lead to an estimated avoidance of 29,000 lives lost and 1.7 million tonnes of crop loss while bringing an economic benefit in present value of 2.7 times more than the total cost incurred in its implementation during the whole period 2010-2050. The results provide useful policy insights and pathways for evidence-based decision-making in the design and effective implementation of SLCP mitigation measures in Nepal.
\end{abstract}

Keywords Short-lived climate pollutants $\cdot$ Hindu Kush Himalayan · Loss of life $\cdot$ Crop loss · Global warming $\cdot$ LEAP-IBC modeling

Electronic supplementary material The online version of this article (https://doi.org/10.1007/s11869-020-00799-6) contains supplementary material, which is available to authorized users.

Amrit M. Nakarmi

nakarmiamrit@gmail.com

1 Department of Mechanical Engineering, Institute of Engineering, Tribhuvan University, Lalitpur, Nepal

2 Center for Energy Studies, Institute of Engineering, Tribhuvan University, Lalitpur, Nepal

3 International Centre for Integrated Mountain Development (ICIMOD), Lalitpur, Nepal

4 Stockholm Environment Institute, Environment Department, University of York, York, UK

5 Department of Mechanical Engineering, University of Colorado, Boulder, CO, USA

\section{Introduction}

Air quality management and climate change mitigation are two inexorably linked environmental challenges of the twenty-first century. Addressing them in a coordinated manner can simultaneously slow down the rate of climate change and protect human health and ecosystems, including agriculture. Yet, air pollutants and greenhouse gases (GHGs) and their impacts are often considered independently in both scientific and policy spheres. $\mathrm{CO}_{2}$ is widely recognized as the primary driver of global warming and climate change. However, studies have shown that short-lived climate pollutants (SLCPs) - including methane $\left(\mathrm{CH}_{4}\right)$, black carbon (BC), and tropospheric ozone $\left(\mathrm{O}_{3}\right)$ - contribute to near-term climate change, as well as adverse impacts on human health and agriculture (IPCC 2014; Ramanathan and Carmichael 2008; UNEP/WMO 2011). Growing evidence suggests that to reduce global warming and remain under a target of $2{ }^{\circ} \mathrm{C}$ rise, 
it is essential to take a coordinated action, without any delay, for reductions in both $\mathrm{CO}_{2}$ and SLCPs concurrently (Bowerman et al. 2013; Hu et al. 2013; Rogelja et al. 2014; Shoemaker et al. 2013; UNEP/WMO 2011). To help address this, several governmental and non-governmental organizations (including the US Environmental Protection Agency, the World Bank, and the Arctic Council) are taking action on SLCP mitigation (Pierrehumbert 2014). In addition, a separate United Nations entity, the Climate and Clean Air Coalition (CCAC), was formed in 2012 as the only global voluntary organization dedicated to promoting and implementing early mitigation of SLCPs by supporting their integration into existing national planning (CCAC 2016b). Clearly, an integrated approach to addressing air quality and climate change as part of the policy process will offer a great opportunity to contribute to meeting sustainable development goals (SDGs), although they are not explicitly stated as such (Haines et al. 2017).

Several studies have identified Asia as the single largest source of global BC emissions from contained combustion, accounting for more than half of all such emissions (Ramanathan and Carmichael 2008; UNEP 2011; USAID 2010). The Hindu Kush Himalayan (HKH) region in South Asia is especially vulnerable to the impacts of SLCPs, in particular to BC. This region is the source of ten large Asian river systems which provide water, ecosystem services, and the basis of livelihoods to more than 210 million people in the mountains and 1.3 billion people downstream (Beniston, cited in Rasul 2014). Studies have shown that glaciers in the HKH region have been retreating and will continue to melt at higher rates if the increase in emissions continues (Ramanathan et al. 2008; Rose 2012; Yongiian et al. 2015). While some of the atmospheric changes in the HKH region are driven by the global increase in atmospheric GHG concentrations, approximately $50 \%$ of the warming on the Himalayan-Tibetan plateau has also been attributed to BC (Menon et al. 2010; Ramanathan et al. 2007; UNEP/WMO 2011). This glacial melting in the $\mathrm{HKH}$ region is due not only to a temperature increase in $\mathrm{CO}_{2}$ but also to the aerosols that arise mainly from burning biomass and fossil fuel combustion (Gustafsson et al. 2009; Ramanathan et al. 2007; Rose 2012; Sadavarte et al. 2016).

Nepal, located between two of the world's biggest BC emitters, China and India (Ramanathan and Carmichael 2008), is particularly vulnerable to the impacts. Thus, domestic action will be insufficient and regional cooperation will be needed to reduce the impacts of SLCPs. However, there is still a data gap on SLCP emissions in Nepal based on their activity levels, emission share, temporal and spatial variation, and quantification of their impacts. Existing policies and plans are largely designed to indirectly support or generate cobenefits for air pollution mitigation without an explicit SLCP-focused policy and planned interventions (Gyawali
2016). Past studies of SLCPs in Nepal are usually either concerned with transboundary atmospheric brown clouds (Lüthi et al. 2015; Rose 2012), or focused at city level and reflect localized data as in the following papers: Rupakheti et al. (2016); Kim et al. (2015); Putero et al. (2015); World Bank (2014); Shrestha et al. (2013b); ICIMOD (2012); Dhimal et al. (2009); CEN/ENPHO (2003). The World Bank reported that the mean annual ambient $\mathrm{PM}_{2.5}$ concentration in Nepal was $46.09 \mu \mathrm{g} / \mathrm{m}^{3}$ in 2013 , and the $\mathrm{PM}_{2.5}$ concentration in Kathmandu in 2013 was $49 \mu \mathrm{g} / \mathrm{m}^{3}$ (WB/IHME 2016; WHO 2016). A more recent study shows that the daily mean $\mathrm{PM}_{2.5}$ and $\mathrm{BC}$ concentrations in Kathmandu valley, due to the transport sector, can reach $124.76 \mu \mathrm{g} / \mathrm{m}^{3}$ and $16.74 \mu \mathrm{g} / \mathrm{m}^{3}$, respectively, during spring (Shakya et al. 2016). Other studies suggest that the urban centers are most vulnerable to impacts of air pollution with pollution levels substantially above WHO guidelines (CANN 2014; CES 2016; DoE 2016; Gautam 2010; ICIMOD 2012; WHO 2016; World Bank 2014). All these studies call for the control of air pollution to reduce its adverse impacts. For this to happen, a proper understanding of the impacts of SLCPs mitigation measures is paramount for evidence-based policy decision-making. In this context, it is very important for Nepal to undertake an assessment of the potential measures that could be taken to mitigate the impacts of SLCPs.

The objective of this study is to provide a guideline or benchmark for the formulation of a national action plan to be undertaken by each of the respective stakeholders and practitioners. Application of the scenario-based approach using the Long-range Energy Alternatives Planning System-Integrated Benefits Calculator (LEAP-IBC) analytical tool for evaluation of the mitigation of SLCPs in this study also provides an example for devising mitigation strategies in other countries in the HKH region.

The paper is organized as follows: the "Methodology and modeling framework" section briefly discusses the methodological framework dealing with mitigation scenario, impact assessment method, and data sources. The "Results and discussion" section presents scenario results and discussion, followed by our conclusion in the "Conclusions and policy implications" section. The detailed methodological framework is provided in the Supplementary Materials for this paper.

\section{Methodology and modeling framework}

This study has been carried out in close compliance with the national SLCP planning process as given by CCAC in the SLCP National Planning Guidance Document (CCAC 2016a). The initial phase comprised a rigorous literature review and consultations with various governmental as well as non-governmental stakeholders and experts on air pollution. 
This phase contributed to assessing the current situation regarding emissions and inventory development. It also provided insights on current activities, policies, plans, and institutional frameworks related to SLCP mitigation. Second, emission estimates were derived for the Reference (REF) scenario, beginning in 2010 and extending to 2050 using a bottom-up approach. Third, an analysis of mitigation options suitable in the context of Nepal was carried out from various documents, with priority given to those identified by a UNEP/WMO assessment report and reports on sectoral mitigation options for SLCPs in the HKH region (MOPE 2014; Sharma 2014; UNEP/WMO 2011; USAID 2010; USEPA 2012). A baseline inventory of emissions was developed. Then, the scenarios were analyzed using the LEAP-IBC modeling framework, with economic and demographic parameters taken as drivers of anthropogenic activities and emissions. Finally, the results were ratified by governmental and non-governmental stakeholders and experts in a validation workshop.

\section{Emission mitigation scenarios}

Based on the economic and demographic situations as primary driving factors, SLCP emission projections and their impacts were examined under Reference (REF) and Policy (POL) scenarios. The year 2015 was taken as the base year for results analysis. Agricultural, commercial, and industrial activities were assumed to be dependent on respective gross value added (GVA) in each emitting sector, while the residential sector and waste outputs were assumed to be dependent on population. The transport sector, on the other hand, is dependent on both economic and demographic parameters for freight and passenger transportation, respectively. The economic and demographic data were retrieved from CBS (2012, 2014), NPC (2017), and World Bank (2013). The assumption of the REF scenario is that the future trend will follow the same path as the current one with no change in current policies. The POL scenario encompasses possible interventions with mitigation measures that are already available and are in practice. The mitigation measures and targets came from the Sustainable Energy for All (SE4ALL) initiative, SDGs of the United Nations, the Water and Energy Vision 2050 (WECS 2013), and low carbon economic development strategies (MOPE 2014). The major mitigation options identified are clean cooking technology, modern energy access, efficiency improvement in industrial processes, efficiency improvement in lighting, efficient mass transportation, renewable energy electricity generation, control on open biomass burning, intermittent aeration of rice field, animal waste management, waste management, and recovery of methane. The major emission factors for various activities were retrieved from Bond et al. (2004, 2013), EMEP/EEA (2013), IPCC (1996, 2006), Shrestha et al. (2013a), and Venkataraman et al. (2010). Details are tabulated in the Supplementary Materials.

\section{Impact assessment method}

Air pollution impacts human health, agriculture, and the environment at local, regional, and global scales. As such, it is necessary to quantify the effect of all emissions from all sources on the ambient pollutant concentrations, and associated impacts on human health, crop loss, and climate. In this work, "adjoint" coefficients, that quantify the sensitivity of a variable (e.g., an air pollution concentration impact metric) to emissions in $2 \times 2.5^{\circ}$ grids globally (see Henze et al. (2007)), from the GEOS-Chem atmospheric chemistry transport model (Bey et al. 2001) were combined with emissions to estimate the following: (1) population-weighted annual average fine particulate matter $\left(\mathrm{PM}_{2.5}\right)$ and the maximum 6-month average daily maximum $1 \mathrm{~h}$ ozone $\left(\mathrm{O}_{3}\right)$ concentrations, relevant for the impacts of these pollutants on human health; (2) 3-month average $\mathrm{O}_{3}$ concentrations across representative growing seasons for four staple crops (rice, wheat, maize, and soy); and (3) radiative forcing in four latitudinal bands (covering the Arctic, northern mid-latitudes, tropics, and southern hemisphere extra-tropics) due to emissions of each pollutant. Concentrationresponse relationships were then applied to estimate the air pollution-attributable premature deaths and air pollutionassociated crop loss and to convert changes in radiative forcing to changes in temperature in each year following emission.

The combination of emissions and adjoint coefficients from the GEOS-Chem model were also used to assess the transboundary effects due to the transport of pollutant emissions from other countries. Outside Nepal, default emissions were used from the International Institute for Applied Systems Analysis (IIASA) ECLIPSE dataset (http://www.iiasa.ac.at/ web/home/research/researchPrograms/air/ECLIPSEv5a.html, Stohl et al. (2015)) for all pollutants. In this study for Nepal, a grid of $2 \times 2.5^{\circ}$ resolution was used to analyze the emissions and their impact at a national scale. An overview of the models and methodology used for impact assessment in this paper is given in the supplementary materials and on the webpage of LEAP-IBC (Heaps 2017).

\section{Economic evaluation}

Economic evaluation of the impacts estimated for reference and policy scenarios in this study includes direct costs and benefits such as investment, cost of operation and maintenance, cost of resources, cost savings on fuel, carbon trade costs, and the economic value of lives and crop loss. It does not include indirect costs such as the cost of health services, income from tourism, employment generation, and ancillary productions. The costs are represented at 2005 constant price with social discount rate of $6 \%$. The economic value of life 
was based on the value of a statistical life (VSL). Limitations of data mean that this has been derived by adjusting the ratio of Nepal's GDP per capita to the EU average GDP per capita. It has been projected that Nepal's best VSL estimate is about 83,000 USD with an uncertainty range of 41,000-124,000 USD (OECD 2012; World Bank 2015). The economic value of crops was estimated from a Food and Agriculture Organization estimate of producer price of each crop (FAOSTAT 2016).

\section{Data sources for emission inventory}

The steps followed in this study include the inventory development for emissions of particulates as well as gaseous emissions. A bottom-up approach was applied to develop the inventory at each activity level. In the REF scenario, the economic sectors were driven by GVA, which were retrieved from economic reports (MoF 2016; NPC 2014; NPC 2017). Another major driver of emissive activities is demography, which includes not only national population growth but also urbanization. These data were taken from CBS $(2012,2014)$. The current status of SLCP emissions in Nepal was derived within the LEAP-IBC modeling framework. The base year in the LEAP-IBC model is 2010. But, as we have passed the year 2016, the year 2015 has been taken as the base year to develop the emission inventory of SLCPs in Nepal. The major sources of energy and non-energy activities and technologies were retrieved from DOF (2016), FAOSTAT (2016), IRENA (2012), Manandhar and Dangol (2013), MOAD (2014), NEEP/GIZ (2012), Pradhan (2004), Shrestha et al. (2012), USEPA (2012), WECS (2010, 2014), and World Bank (2012). The sectors included in the study in addition to activity level data and emission parameters are given in the Supplementary Materials. The 2015 SLCP inventory is given in the "Emissions" section.

\section{Uncertainty analysis}

Uncertainties can arise from various factors such as inaccuracy in emission monitoring, lack of knowledge involving the emission factor, and activity data estimates. The uncertainty analyses for GHG emissions have also been recommended from the guidance by IPCC, and the method most commonly used in practice for uncertainty analysis is Monte Carlo simulation (IPCC 2000). In this study, the uncertainties are calculated at $95 \%$ confidence interval for energy and non-energy sectors using Monte Carlo simulation with 10,000 iterations. Sensitivity analysis has also been performed to examine the extent of variations in the results for $\mathrm{BC}, \mathrm{CH}_{4}, \mathrm{PM}_{2.5}$, and GHG emissions due to input parameters.

\section{Results and discussion ${ }^{1}$}

\section{Emissions}

The emission inventory for 2015 was developed as the first step in results analysis. Table 1 shows the emission of different SLCPs and air pollutants from different sectors in 2015 from fuel and non-fuel combustion, as well as the selected chemical process.

The results of both the REF and the POL scenarios, obtained from the LEAP-IBC modeling framework, are shown in Table 2. The table indicates that, with the policy intervention of different strategic measures (see Supplementary Materials), emissions of $\mathrm{BC}$ and $\mathrm{PM}_{2.5}$ can be greatly reduced in 2050 from their values in 2010. Similarly, emissions of $\mathrm{CH}_{4}$ and GHGs in 2050 can be reduced to near their values in 2010.

From the perspective of sources, residential and commercial sectors are the prime sources of air pollutants. Thus, any strategy must place a strong emphasis on this sector. Meanwhile, in other sectors such as transport and industries, stringent pollution control regulations can help reduce pollution. The remaining sources either require low-emissive technological transformation or awareness to reduce emissive activities, such as reducing the open burning of wastes and biomass and waste reuse and recycle.

\section{Impact analysis of scenarios for mitigation of SLCPs}

The "Emissions" section described the overall emissions of various pollutants and climate forcers. However, the real measure that concerns everybody is their environmental impacts. This analysis does not include analysis of uncertainties on impact due to variations in $\mathrm{BC}, \mathrm{CH}_{4}, \mathrm{PM}_{2.5}$, and $\mathrm{GHG}$ emissions. However, the uncertainty analysis for emission level for each pollutant is covered in the "Uncertainties in emissions and sensitivity analysis" section.

\section{$\mathrm{PM}_{2.5}$ concentration}

The national population-weighted annual average $\mathrm{PM}_{2.5}$ concentration was $47 \mu \mathrm{g} / \mathrm{m}^{3}$ in 2015 , substantially above the WHO standard of $10 \mu \mathrm{g} / \mathrm{m}^{3}$ (WHO 2006). This value includes not only contributions from national emissions but also the influence of natural sources and transboundary emissions. The latter is estimated to make the larger contribution to national population-weighted $\mathrm{PM}_{2.5}$ concentrations, contributing almost $50 \%$ (Fig. 1). The reduction in $\mathrm{PM}_{2.5}$ concentrations has significant benefits, and these are discussed in the "Premature deaths avoided," "Loss of crop yield mitigated,"

\footnotetext{
${ }^{1}$ The results and figures presented in this chapter have been derived from LEAP (Heaps 2016).
} 
Table 1 Major short-lived climate pollutants and particulate matter (tonnes) from different sectors in Nepal in 2015

\begin{tabular}{llll}
\hline & Black carbon & $\begin{array}{l}\text { Methane } \\
\text { Tonnes }\end{array}$ & $\mathrm{PM}_{2.5}$ \\
\hline Agriculture & 575 & 57 & 748 \\
Commerce & 871 & 3380 & 4599 \\
Industry & 1590 & 363 & 4958 \\
Industrial process & 1 & 0 & 163 \\
Livestock farming & 0 & 607,965 & 0 \\
Rice cultivation & 0 & 126,633 & 0 \\
Open burning & 4662 & 41,418 & 64,732 \\
Residential & 25,428 & 120,046 & 145,716 \\
Transport & 6426 & 265 & 16,948 \\
Waste management & 73 & 129,983 & 1103 \\
Total & 39,626 & 1030,110 & 238,967 \\
\hline
\end{tabular}

"Impact on global temperature," and "Economic evaluation of policy intervention" sections.

\section{Premature deaths avoided}

The most visible and significant impact of air pollution is on human health. Figure 2 indicates that reducing $\mathrm{PM}_{2.5}$ and $\mathrm{O}_{3}$ can help reduce large-scale health risks. Emissions from all sources in 2010 and 2015 resulted in an estimated annual air pollution health burden of 23,000 and 30,000 premature deaths, respectively; this accounts for around 1 per 1000 people. Given these figures, the REF scenario suggests that, if no mitigation strategies are implemented, the estimated air pollution-associated health burden increases to 50,000 premature deaths in 2030 and 109,000 premature deaths in 2050, with nearly $88 \%$ premature deaths due to $\mathrm{PM}_{2.5}$. In addition to increasing $\mathrm{PM}_{2.5}$ and $\mathrm{O}_{3}$ concentrations, these figures also reflect increases in, and aging of, Nepal's population.

With mitigation measures taken, the estimated total premature deaths from anthropogenic sources in Nepal in the POL scenario are reduced by 11,000 and 29,000 in 2030 and 2050, respectively. However, nearly $57 \%$ of premature deaths in the REF scenario are estimated to result from emissions outside Nepal. In the POL scenario, $77 \%$ of estimated premature deaths in 2050 are the result of transboundary air pollution because of a reduction in premature deaths due to national emissions. Thus, it is essential to take regional-level mitigation action to reduce transboundary emissions.

\section{Loss of crop yield mitigated}

The impact of ozone on four major crops (rice, wheat, maize, and soy) was assessed and was again mainly due to transboundary emissions. Thus, it is crucial that this issue of transboundary emission is addressed in the context of food security. The results indicate that crop losses can be greatly reduced in the POL scenario compared with the REF scenario (Fig. 3).

\section{Impact on global temperature}

One of the greatest concerns is the global warming due to pollutant release. The temperature increment is found to grow in future years, with SLCPs being the dominant factor. Thus, mitigation strategies for control of SLCPs are as important as those for GHGs to reduce Nepal's contribution to global temperature increases. Figure 4 shows the temperature increment with reference to the temperature level in 2010. It can be seen that the temperature increment in the POL scenario before 2055 is higher than in the REF scenario. This is due to the dominant effect of cooling caused by aerosols. However, beyond this date, the reductions in $\mathrm{CH}_{4}, \mathrm{CO}_{2}$, and $\mathrm{O}_{3}$ precursors will ultimately reduce Nepal's contribution to global temperature increases in the POL scenario. As major SLCPs decrease and GHG emissions are controlled, the temperature increment will be much slower than in the REF scenario, remaining below $2 \mathrm{mK}$ in 2100 .
Table 2 Emissions in various years in reference and policy scenarios, in thousand tonnes

\begin{tabular}{llllllll}
\hline Pollutant & Scenarios & 2010 & 2015 & 2020 & 2030 & 2040 & 2050 \\
\hline BC & REF & 35.4 & 39.6 & 42.3 & 48.0 & 56.0 & 73.5 \\
& POL & 35.4 & 39.6 & 25.5 & 6.4 & 6.2 & 5.5 \\
$\mathrm{CH}_{4}$ & $\mathrm{REF}$ & 934 & 1030 & 1256 & 1875 & 2801 & 4126 \\
& POL & 934 & 1030 & 938 & 580 & 734 & 919 \\
PM2.5 & REF & 228 & 239 & 250 & 273 & 302 & 376 \\
\multirow{2}{*}{ Greenhouse gases* } & POL & 228 & 239 & 176 & 72 & 63 & 48 \\
& REF & 72,319 & 83,078 & 101,210 & 153,331 & 232,769 & 350,327 \\
& POL & 72,319 & 83,078 & 76,131 & 50,058 & 64,910 & 83,783 \\
\hline
\end{tabular}

$P O L$, policy; $R E F$, reference

${ }^{*} \mathrm{As} \mathrm{CO}_{2}$ equivalents assuming a 20-year Global Warming Potential 
Fig. $1 \mathrm{PM}_{2.5}$ concentrations in Nepal in various years in reference and policy scenarios. REF, reference; POL, policy

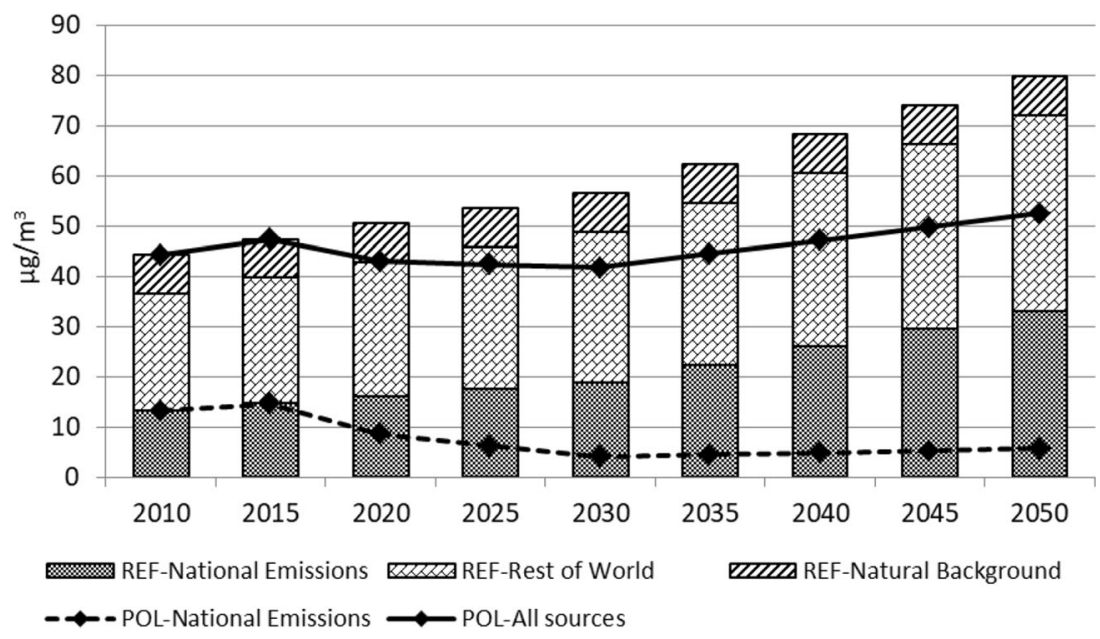

\section{Economic evaluation of policy intervention}

The cost of mitigation options is high in the energy sector, primarily because of the hydropower development. However, economic benefits due to a reduction in fuel imports, premature mortality, and crop losses are even larger. The costs of mitigation in the non-energy sector are higher than returns. But, owing to its huge contribution to emissions, and its impact, mitigation steps must be undertaken. At net present value, the overall investment and operating cost of implementing mitigation measures throughout the policy scenario sum to 21 billion USD, while the net benefit of 57 billion USD can be achieved. If the energy and non-energy mitigation strategies are implemented together, the benefits from the energy sector pay-off for the cost in the non-energy sector-and the overall benefit - are still positive. The net return is positive, with a benefit-to-cost ratio of 2.7. Thus, overall, the results indicate that the POL scenario is not only technically viable but also economically feasible.

The above economic analysis gives an important insight: mitigation options and activities not only are dependent on each other but also make the implementation process economically more viable if applied altogether. Thus, there must be inter-sectoral cooperation for implementation of the targets set to reduce SLCPs as well as GHG emissions. The economic analysis does not address the uncertainty ranges of SLCPs and the subsequent effects on other climate change benefits.

\section{Uncertainties in emissions and sensitivity analysis}

The variance propagation at $95 \%$ confidence interval of $\mathrm{BC}$, $\mathrm{CH}_{4}, \mathrm{PM}_{2.5}$, and $\mathrm{GHG}$ emissions showed that the variance range reduces over time. The variance range in the POL scenarios narrows compared with the REF scenario fall for all four pollutants. In the POL scenario, the uncertainty range of $\mathrm{BC}$ reduces from $26-45 \mathrm{kt}$ in 2015 to $5-9 \mathrm{kt}$ in 2050 . Similarly, that for $\mathrm{CH}_{4}$ narrows down from $0.8-1.3 \mathrm{Mt}$ in 2015 to $0.7-1.1 \mathrm{Mt}$ in 2050 and that for $\mathrm{PM}_{25}$ reduces from $200-280 \mathrm{kt}$ in 2015 to $44-64 \mathrm{kt}$ in 2050 . The GHG uncertainty narrows down by little, from 29-43 Mt in 2015 to $38-49 \mathrm{Mt}$ in 2050. These reductions in uncertainty range are due to switching to cleaner fuels with lower emission potential in
Fig. 2 Premature deaths in Nepal in reference and policy scenarios. REF, reference; POL, policy

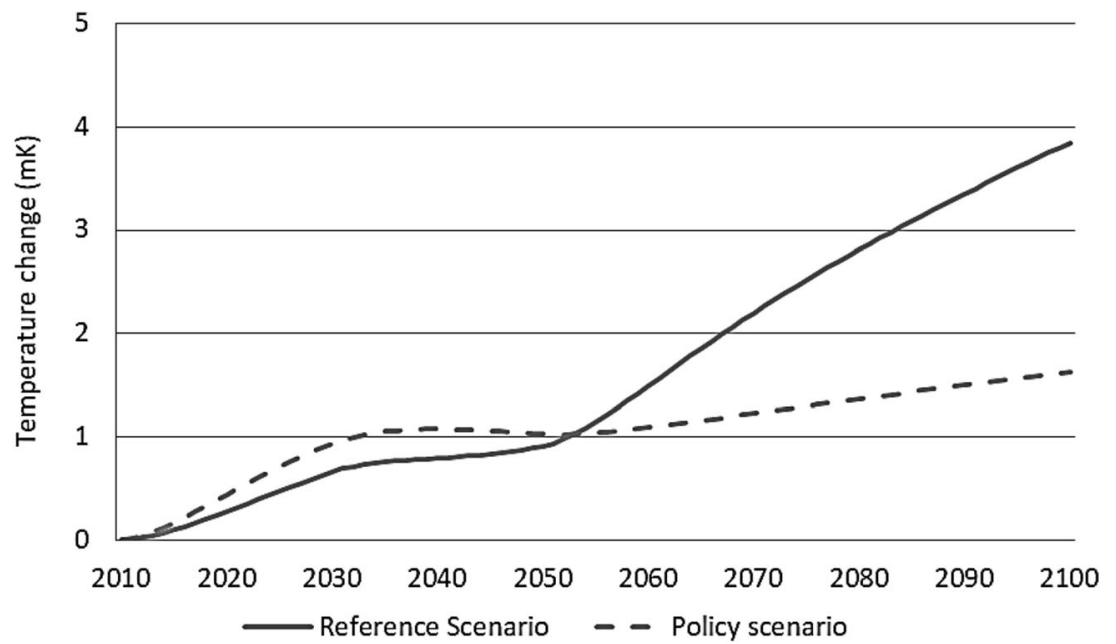


Fig. 3 Crop yield loss in Nepal in reference and policy scenarios

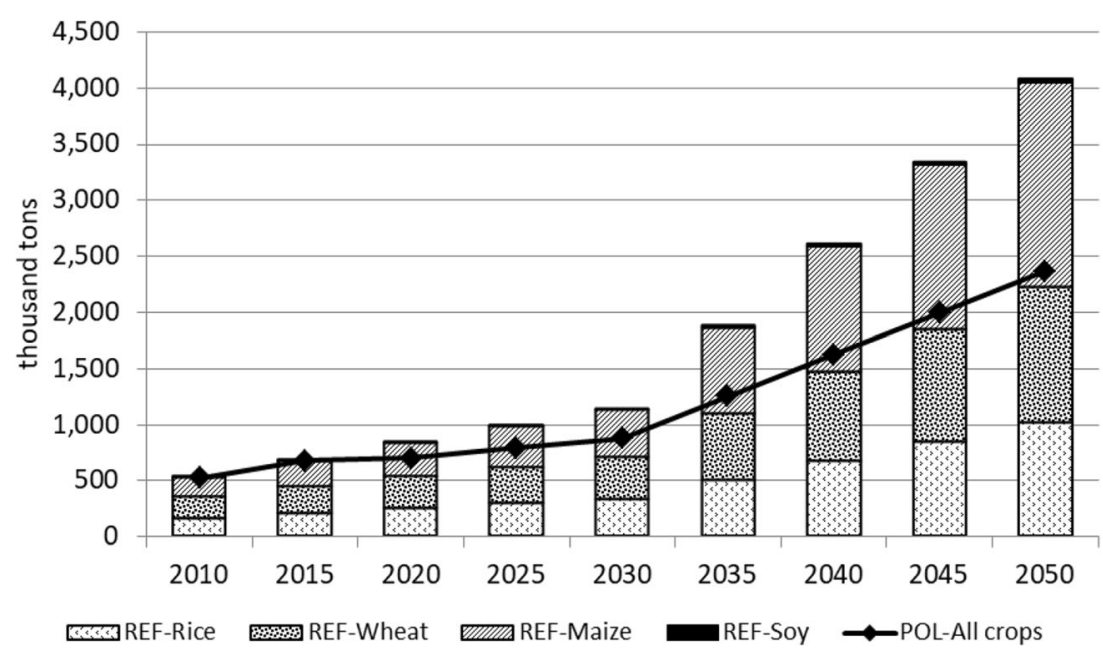

the POL scenario. The sensitivity analysis for $\mathrm{BC}$ shows that the residential fuelwood emission factor and consumption make the major contribution to the variance in $\mathrm{BC}$ emission. The sensitivity analysis for $\mathrm{CH}_{4}$ shows that the emission is most sensitive to emission factors of livestock farming, residential fuelwood, waste, and rice cultivation. Similarly, the sensitivity analysis shows that the variance in the emission of $\mathrm{PM}_{2.5}$ is highly sensitive to the residential sector. Forest fires and emission factors of industrial coal and diesel consumption in transport are also major contributors to emission variance. Sensitivity analysis shows that in the REF scenario, the emission factor of livestock farming - including fermentation and manure management - makes the greatest contribution to variance in GHG emissions, followed by emission factors for $\mathrm{CH}_{4}$ and $\mathrm{N}_{2} \mathrm{O}$ of residential fuelwood.

\section{Conclusions and policy implications}

This study shows that the emissions and impacts of SLCPs in Nepal are significant with the major sources of $\mathrm{BC}$ and $\mathrm{PM}_{2.5}$ being biomass burning in the residential sector and fuel combustion in transport. The major source of $\mathrm{CH}_{4}$ emissions is agricultural activities followed by the residential sector and waste management. As anthropogenic activities increase, emission levels rise, contributing to adverse climate and air pollution impacts. If mitigation measures are taken in the POL scenario, $78 \%$ of $\mathrm{BC}, 78 \%$ of $\mathrm{CH}_{4}$, and $87 \%$ of $\mathrm{PM}_{2.5}$ emissions can be avoided in 2050 compared with the REF scenario. The national, populationweighted $\mathrm{PM}_{2.5}$ concentration of $47 \mu \mathrm{g} / \mathrm{m}^{3}$ in 2015 can be limited to $52 \mu \mathrm{g} / \mathrm{m}^{3}$ in 2050 compared with $80 \mu \mathrm{g} / \mathrm{m}^{3}$ in the REF scenario. Similarly, 29,000 premature deaths and 1.7 million tonnes of crop loss can be avoided annually by 2050 in the POL scenario compared with the REF scenario. The benefitcost analysis indicates that there is a net economic saving of 36 billion USD (2005 constant price) if the strategic measures are undertaken in a timely manner. The impact on global climate due to emissions in Nepal could also be reduced by limiting temperature increment within $2 \mathrm{mK}$ in 2100 in the POL scenario from near to $4 \mathrm{mK}$ in the REF scenario. An estimated reduction of $58 \%$ can be achieved in 2100 if all the mitigation strategies are implemented.
Fig. 4 Global average equilibrium temperature changes due to emissions in Nepal

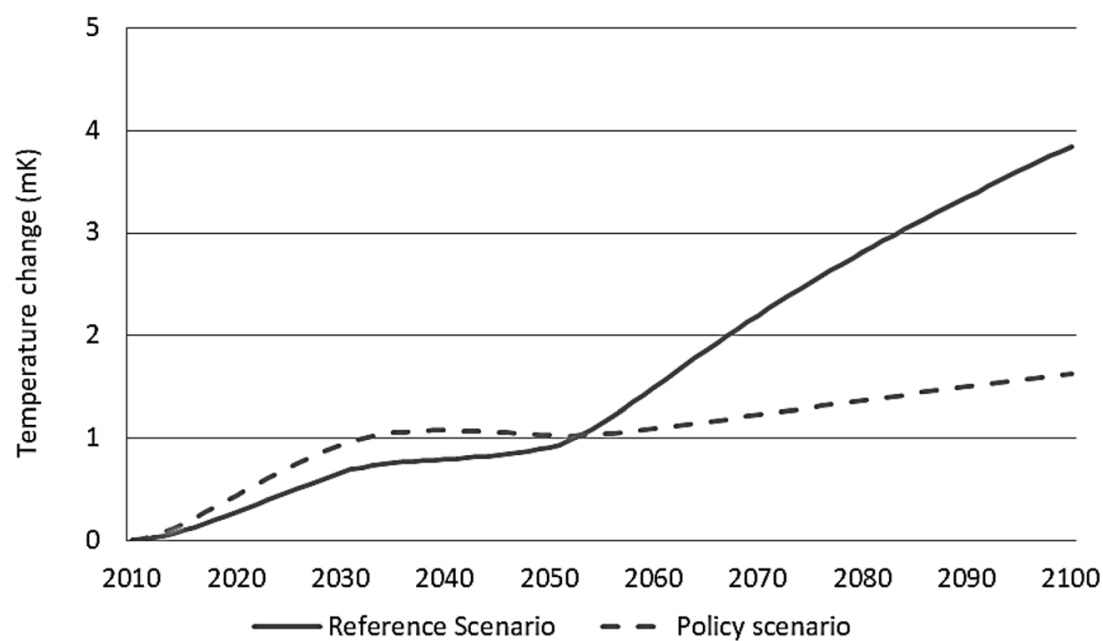


Air pollution is not limited to a local area but has regional as well as global impacts. This paper suggests that emissions from the HKH region and beyond have a major influence on pollution levels and their impacts in Nepal, owing to the transboundary transport of pollutants. More than $50 \%$ of the $\mathrm{PM}_{2.5}$ concentration in Nepal was estimated to result from emissions outside the country. The situation in the rest of the HKH region is no different, as suggested by other studies as well (Kurokawa et al. 2013). This raises the need for regional cooperation among countries in the HKH region to act jointly in effective mitigation of SLCPs and reducing their impacts in the region. It is also essential that voices are raised in international organizations like UNEP and CCAC, requesting the necessary assistance in mitigating SLCPs, as the transboundary effects are at a much larger scale than the national-level effects.

These scenarios and results suggest that mitigation practices should be implemented as soon as possible, not only in Nepal but in other countries of the HKH region as well. The mitigation technologies are readily available, and supporting policies need to be devised and implemented. The inclusion and prioritization for mitigation of SLCPs in national policy are of utmost importance as their climate impacts are higher and short term in nature. Overall, coordinating this with similar and relevant strategies in the regional context can benefit the whole HKH region as well.

Several policy pathways could be followed for effective implementation of SLCP mitigation measures in Nepal that are so crucial for achieving several SDGs: from their role in reducing poverty to combating climate change, and engaging in adaption and mitigation. Developing an integrated approach to both air pollution abatement and climate change during the policy process is perhaps the most desirable pathway to maximize synergy, thereby making the public policy process more effective and efficient. Another pathway would be to build SLCP abatement policies on existing national development policies and initiatives. Integration of the economic costs of pollution into product pricing would incentivize consumers to make more informed choices, while at the same time creating pressure on producers to reduce their pollution footprint and adopt better practices. However, this calls for creating and supporting enabling conditions to confront a broad range of existing barriers to the design and implementation of national SLCP mitigation strategies. These include the need for a strong science-policy interface to raise awareness; data on pollution and its impacts; a dedicated regulatory institution with resources and capacity for effective implementation, monitoring, and enforcement; and changing the entrenched social norm and behavior of citizens.

Acknowledgments The authors are immensely grateful to the Stockholm Environment Institute (SEI) for making available and conducting training on the LEAP-IBC software module. We are thankful to Mr. Krishna
Gyawali for sharing his knowledge on policy gap analysis of Nepal, and to Maheswor Rupakheti, IASS Potsdam, for insightful recommendations regarding SLCPs. We would also like to show our gratitude to Eklabya Sharma, Mats Eriksson, Bhupesh Adhikari, Prakash Bhave, and Karuna Bajracharya for their valuable opinions and suggestions during the study. We would also like to acknowledge Elaine Monaghan for her conscientious editing of the manuscript. This research was conducted under the Atmosphere Initiative at the International Centre for Integrated Mountain Development (ICIMOD).

Funding information The research was partially supported by core funds from ICIMOD contributed by the governments of Afghanistan, Austria, Bangladesh, Bhutan, China, India, Myanmar, Nepal, Norway, Pakistan, Switzerland, and the UK.

\section{Compliance with ethical standards}

Disclaimer The views and interpretations expressed in this paper are those of the authors.

Open Access This article is licensed under a Creative Commons Attribution 4.0 International License, which permits use, sharing, adaptation, distribution and reproduction in any medium or format, as long as you give appropriate credit to the original author(s) and the source, provide a link to the Creative Commons licence, and indicate if changes were made. The images or other third party material in this article are included in the article's Creative Commons licence, unless indicated otherwise in a credit line to the material. If material is not included in the article's Creative Commons licence and your intended use is not permitted by statutory regulation or exceeds the permitted use, you will need to obtain permission directly from the copyright holder. To view a copy of this licence, visit http://creativecommons.org/licenses/by/4.0/.

\section{References}

Bey I, Jacob D J, Yantosca R M, Logan J A, Field B D, Fiore A M, et al (2001) Global modeling of tropospheric chemistry with assimilated meteorology: model description and evaluation. J Geophys Res 23073-23095

Bond TC, Streets DG, Yarber KF, Nelson SM, Woo J-H, Klimont Z (2004) A technology-based global inventory of black and organic carbon emissions from combustion. J Geophys Res 109

Bond TC, Doherty SJ, Fahey D, Forster P, Berntsen T, DeAngelo B, et al (2013) Bounding the role of black carbon in the climate system: a scientific assessment. J Geophys Res: Atmospheres 5380-5552

Bowerman N H, Frame D J, Huntingford, C, Lowe J A, Smith S M, \& Allen M R (2013) The role of short-lived climate pollutants in meeting temperature goals. Nat Clim Change

Cann C (2014) Air quality status and management in Kathmandu Valley. MaYA Fact Sheet \#5. UNHABITAT, Kathmandu

CBS (2012) National population and housing census 2011. Central Bureau of Statistic, National Planning Commission Secretariat, Government of Nepal, Kathmandu

CBS (2014) Population monograph of Nepal. Central Bureau of Statistics, Kathmandu

CCAC (2016a) SLCP National Planning Guidance Document. Climate and Clean Air Coalition, Paris

CCAC (2016b) About us. Retrieved July 2016, from Climate and Clean Air Coalition: http://www.ccacoalition.org/en/content/about-us/

CEN/ENPHO (2003) Health impacts of Kathmandu's air pollution. Prepared for KEVA Secretariat under USAID/Nepal, Clean Energy 
Nepal (CEN) and Environment and Public Health Organization (ENPHO)

CES (2016) Study of diesel generator micro-grid design to reduce emission in Kathmandu Valley. Center for Energy Studies, Institute of Engineering, Tribhuvan University, Lalitpur, Nepal

Dhimal, M, Bhattarai, L, \& Bhusal, C L (2009) Situation analysis of environmental health in Nepal 2009. World Health Organization; Nepal Health Research Council. Kathmandu: Nepal Health Research Council

DoE (2016) National pollution control strategy and action plan. Draft, Department of Environemnt, Ministry of Population and Environment, GOvernment of Nepal, Lalitpur, Nepal

DOF (2016) Forest fire data. Excel Sheet Database, Department of Forests, Ministry of Forests and Soil Conservation, Government of Nepal, Kathmandu, Nepal

EMEP/EEA (2013) EMEP/EEA air pollutant emission inventory guidebook. European Environment Agency

FAOSTAT (2016) FAOSTAT - data. Retrieved 2016, from http://www. fao.org/faostat/en/\#data

Gautam D (2010) Air pollution: its causes and consequences with reference to Kathmandu metropolitan city. Third Pole 8-10:27-33

Gustafsson O, Krusa M, Zencak Z, Rebecca SJ, Granat L, Engstrom E (2009) Brown clouds over South Asia: biomass or fossil fuel combustion? Science 323(5913):495-498

Gyawali K (2016) Analysis of short-lived climate pollutants (SLCPs) related policies in Nepal. Prepared for ICIMOD

Haines A, Amann M, Borgford-Parnell N, Leonard S, Kuylenstierna J, Shindell D (2017) Short-lived climate pollutant mitigation and the sustainable development goals. Nat Clim Chang 7(12):863-869

Heaps C (2016) Long-range energy alternatives planning (LEAP) system. [software version: 2017.0.11]. Stockholm Environment Institute, Somerville https://www.energycommunity.org. Accessed 2017

Heaps C (2017) IBC: the Integrated Benefits Calculator. Retrieved 2017, from https://www.energycommunity.org/default.asp?action=IBC

Henze D, Hakami A, Seinfeld J (2007) Development of the adjoint of GEOS-Chem. Atmos Chem Phys 7(9):2413-2433

$\mathrm{Hu} \mathrm{A}, \mathrm{Xu}$ Y, Tebaldi C, Washington W M, Ramanathan V (2013) Mitigation of short-lived climate pollutants slows sea-level rise. Nat Clim Change 730-734

ICIMOD (2012) Rapid urban assessment of air quality for Kathmandu, Nepal. International Centre for Integrated Mountain Development (ICIMOD), Kathmandu

IPCC (1996) Revised 1996 IPCC guidelines for national greenhouse gas inventories. Intergovernmental Panel on Climate Change

IPCC (2000) Good practice guidance and uncertainty management in national greenhouse gas Inventories [chapter 2: energy]. Intergovernmental Panel on Climate Change

IPCC (2006) Guidelines for national greenhouse gas inventories. Intergovernmental Panel on Climate Chang. Intergovernmental Panel on Climate Change

IPCC (2014) Climate change 2014: synthesis report. Contribution of working groups I, II and III to the fifth assessment report of the intergovernmental panel on climate change [Core writing team, R.K. Pachauri and L.A. Meyer (eds.)]. IPCC, Geneva, Switzerland

IRENA (2012) Renewable energy cost analysis: solar photovoltaics. International Renewable Energy Agency

Kim BM, Park J-S, Kim S-W, Kim H, Jeon H, Cho C et al (2015) Source apportionment of PM10 mass and particulate carbon in the Kathmandu Valley, Nepal. Atmos Environ 123:190-199

Kurokawa J, Ohara T, Marikawa T, Hanayama SGJ, Fukui T (2013) Emissions of air pollutants and greenhouse gases over Asian regions during 2000-2008: regional emission inventory in ASia (REAS) version 2. Atmos Chem Phys 13:11019-11058
Lüthi Z L, Škerlak B, Kim S-W, Lauer A, Mues A, Rupakheti M, et al (2015) Atmospheric brown clouds reach the Tibetan Plateau by crossing the Himalayas. Atmos Chem Phys 6007-6021

Manandhar UM, Dangol SB (2013) Study on evaluating energy conservation potential of brick production in SAARC countries - a report on Nepal. MinErgy Initiatives, Nepal

Menon S, Koch D, Beig G, Sahu S, Fasullo J, Orlikowski D (2010) Black carbon aerosols and the third polar ice cap. Atmos Chem Phys $4559-4571$

MOAD (2014) Statistical information of Nepalese agriculture . Ministry of Agricultural Development

MoF (2016) Economic survey fiscal year 2015/16. Ministry of Finance, Government of Nepal

MOPE (2014) Low carbon economic development strategy, Nepal, 2071. Draft, Ministry of Science, Technology \& Environment

NEEP/GIZ (2012) Baseline Study of Selected Sector Industries to assess the Potentials for more Efficient use of Energy. epal Energy Efficiency Programme (NEEP)/ GIZ, Lalitpur, Nepal

NPC (2014) An approach to the graduation from the least developed country by 2022. National Planning Commission, Government of Nepal, Kathmandu

NPC (2017) 14th three year plan. National Planning Commission, Government of Nepal, Kathmandu

OECD (2012) Mortality risk valuation in environment, health and transport policies. Organisation for Economic Co-operation and Development. OECD Publishing

Pierrehumbert R (2014) Short-lived climate pollution. Annual review of earth and planetary sciences, pp. 341-379

Pradhan S (2004) An investment option in transport sector through clean development mechanism: a case study of trolley buses in ring road. Thesis, Department of Mechanical Engineering, Institute of Engineering, Lalitpur, Nepal

Putero D, Marinoni P C, Adhikary B, Duchi R, Shrestha SD, Verza G P, et al (2015) Seasonal variation of ozone and black carbon observed at Paknajol, an urban site in the Kathmandu Valley, Nepal. Atmos Chem Phys 13957-13971

Ramanathan V, Carmichael G (2008) Global and regional climate changes due to black carbon. J Nat Geosci 221-227

Ramanathan V, Ramana M V, Roberts G, Kim D, Corrigan C, Chung C, et al (2007) Warming trends in Asia amplified by brown cloud solar absorption. Nature 575-578

Ramanathan V, Agrawal M, Akimoto H, Aufhammer M, Devotta S et al (2008) Atmospheric brown clouds: regional assessment report with focus on Asia. United Nations Environment Programme, Nairobi

Rasul G (2014) Food, water, and energy security in South Asia: a nexus perspective from the Hindu Kush Himalayan region. Environ Energy Policy 35-48

Rogelja J, Schaeffer M, Meinshausen M, Shindellg DT, Hare W, Klimont $\mathrm{Z}$ et al (2014) Disentangling the effects of CO2 and short-lived climate forcer mitigation. Proc Natl Acad Sci

Rose E (2012) The ABCs of governing the Himalayas in response to glacial melt: atmospheric brown clouds, black carbon, and regional cooperation. Sustain Dev Law Policy 33-37:65-67

Rupakheti D, Praveen P S, Rupakheti M, Kang S, Mahata K S, et al (2016) Pre-monsoon air quality over Lumbini, a world heritage site along the Himalayan foothills. Atmos Chem Phys Discuss 2016430

Sadavarte P, Venkataraman C, Cherian R, Patil N, Madhavan B, Gupta T, et al (2016) Seasonal differences in aerosol abundance and radiative forcing in months of contrasting emissions and rainfall over northern South Asia. Atmos Environ 512-523

Shakya K M, Rupakheti M, Shahi A, Maskey R, Pradhan B, Panday A, et al (2016) Near-road sampling of PM2.5, BC, and fine particle chemical components in Kathmandu Valley, Nepal. Atmos Chem Phys 
Sharma B (2014) Mitigation options for short-lived climate pollutants in the HKH region - baseline state of the art report. ICIMOD, Lalitpur

Shoemaker J K, Schrag D P, Molina M J, \& Ramanathan V (2013) What role for short-lived climate pollutants in mitigation policy? Science $1323-1324$

Shrestha R, Ahmed M, Suphachalasai S, Lasco R (2012) Economics of reducing greenhouse gas emissions in South Asia. Asian Development Bank, Mandaluyong City

Shrestha R, Kim Oanh NS, Permadi D, Kanabkaew T, Iyngararasan M (2013a) Atmospheric brown clouds (ABC) emission inventory manual. United Nations Environment Programme, Nairobi

Shrestha SR, Oanh NT, Xu Q, Rupakheti M (2013b) Analysis of the vehicle fleet in the Kathmandu Valley for estimation of environment and climate co-benefits of technology intrusions. Atmos Environ 81: $579-590$

Stohl A, Aamaas B, Amann M, Baker L H, Bellouin N, Berntsen T K, et al (2015) Evaluating the climate and air quality impacts of shortlived pollutants. Atmos Chem Phys 10529-10566

UNEP (2011) Near-term climate protection and clean air benefits: actions for controlling short-lived climate forcers. United Nations Environment Programme (UNEP), Nairobi

UNEP/WMO (2011) Integrated assessment of black carbon and tropospheric ozone. United Nations Environment Programme and World Meteorological Organization

USAID (2010) Black carbon emissions in Asia: sources, impacts and abatement opportunities. ECO-Asia Clean Development and Climate Program, United States Agency for International Development

USEPA (2012) Reducing black carbon emissions in South Asia: low cost opportunities. U.S. Environmental Protection Agency

Venkataraman C, Sagar A, Habib G, Lam N, Smith K (2010) The Indian national initiative for advanced biomass cookstoves: the benefits of clean combustion. Energy Sustain Dev 63-72
WB/IHME (2016) The cost of air pollution: strengthening the economic case for action. World Bank and Institute for Health Metrics and Evaluation. World Bank, Washington, DC

WECS (2010) Energy sector synopsis report. Water and Energy Commission Secretatriate, Kathmandu

WECS (2013) Water and energy vision 2050. Water and energy commission secretariat. Government of Nepal, Kathmandu

WECS (2014) National survey of energy consumption and supply situation in Nepal. Water and Energy Commission Secretariat, Government of Nepal, Kathmandu

WHO (2006) WHO air quality guidelines or particulate matter, ozone, nitrogen dioxide and sulfur dioxide. World Health Organization. Geneva, Switzerland: WHO Press

WHO (2016) WHO global urban ambient air pollution database (update 2016). Retrieved 2017, from http://www.who.int/phe/health_topics/ outdoorair/databases/cities/en/

World Bank (2012) What a waste: a global review of solid waste management. World Bank

World Bank (2013) Managing Nepal's Urban Transition. Retrieved 2016, https://www.worldbank.org/en/news/feature/2013/04/01/managingnepals-urban-transition

World Bank (2014) Diesel power generation: inventories and black carbon emission in Kathmandu Valley, Nepal. The World Bank, Washington DC 20433: World Bank Publication

World Bank (2015) Retrieved 2016, from http://data.worldbank.org/ indicator/

Yongjian D, Shiyin L, Jing L, Donghui S (2015) The retreat of glaciers in response to recent climate warming inwestern China. Retrieved May 22, 2016, from Research Gate: https://www.researchgate.net/ publication/233556469_Glaciers_in_response_to_recent_climate_ warming_in_Western_China. Accessed 22 May 2016

Publisher's note Springer Nature remains neutral with regard to jurisdictional claims in published maps and institutional affiliations. 